\title{
INTEGRASI PERAN PENDIDIKAN TINGGI DALAM PENGUATAN SEKTOR UMKM
}

\author{
Rousdy Safari Tamba \\ Institut Ilmu Sosial dan Manajemen STIAMI \\ rousdy@stiami.ac.id
}

\begin{abstract}
Abstrak. Pendidikan memiliki korelasi yang tinggi terhadap pertumbuhan ekonomi, salah satunya melalui pemguatan Usaha Mikro, Kecil dan Menengah (UMKM) Peningkatan Linkage Pendidikan Tinggi Terhadap UMKM, dengan tri dharma perguruan tinggi, dapat diwujudkan dalam Rencana Strategis (RENSTRA) Perguruan Tinggi, dalam bentuk (1) membentuk Jaringan Kerjasama dengan UMKM; (2) Melaksanakan kegiatan Road Show Kerjasama dengan UMKM; (3) Mengembangkan program magang komprehensif berdasarkan pendekatan proyek; dan (4) Pengembangan brand equity dan eksposur kelembagaan dengan keterlibatan lembaga dalam kegiatan-kegiatan profesional melalui penguatan fungsi strategis laboratorium dan lembaga kajian.
\end{abstract}

\section{Kata Kunci : Peran Pendidikan Tinggi, Sektor UMKM}

Abstrac. Education has high correlation on economic growth of a country. An increase in linkage higher education against small and medium businesses Micro, Small, Medium Enterprises, with tri dharma college, can be manifested in the strategic plan (Renstra) college, in the form of (1) forming a network cooperation with Micro, Small, Medium Enterprises ; ( 2 ) Implementing activities road show cooperation with Micro, Small, Medium Enterprises; ( 3 ) to develop a comprehensive internship program based on project approach; and (4) the development of brand equity and exposure of institutional with the involvement of an agency in the professional activities through strengthening strategic functions and institutions for the laboratory study.

Keywords : The role of higher education, Micro, Small, Medium Enterprises

\section{Peran dan fungsi Usaha Mikro, Kecil dan Menengah (UMKM) dalam} pembangunan dan pertumbuhan ekonomi Indonesia memainkan peranan yang sangat vital bahkan tidak saja di negara-negara sedang berkembang, tetapi juga di negaranegara maju. Perkembangan sektor UMKM hingga saat ini jumlahnya telah menggelembung sedemikian besar bahkan hampir menyamai jumlah mereka yang bekerja di sektor formal lainnya. Di banyak negara-negara miskin dan berkembang, kontribusi yang bisa diberikan oleh pelaku usaha kecil mencapai 30\%-60\% dari seluruh penduduk perkotaan. Sedangkan di wilayah Jawa jumlah pelaku sektor ini berkisar antara $37 \%$ sampai $43 \%$, sementara di luar Jawa lebih banyak lagi berkisar antara $40 \%-55 \%$. Dengan begitu saat ini tidak bisa dikatan lagi bahwa sektor usaha kecil dan menengah cuma sebagai tempat penampungan sementara bagi para pekerja yang belum bisa masuk ke sektor formal lainnya, tetapi keberadaannya justru sebagai motor pertumbuhan aktivitas ekonomi (perkotaan) karena jumlah penyerapan tenaga kerjanya yang demikian besar (sama dengan jumlah tenaga kerja di sektor formal).

Eksistensi UMKM memang tidak dapat diragukan lagi karena terbukti mampu bertahan dan menjadi roda penggerak ekonomi. Pada tahun 2011 UMKM mampu berandil besar terhadap penerimaan Negara dengan menyumbang 61,9 persen pemasukan produk domestik bruto (PDB) melalui pembayaran pajak, yang diuraikan sebagai berikut: sektor usaha mikro menyumbang 36,28 persen PDB, sektor usaha kecil 10,9 persen, dan sektor usaha menengah 14,7 persen melalui pembayaran pajak. Sementara itu, sektor usaha besar hanya menyumbang 
38,1 persen PDB melalui pembayaran pajak (BPS, 2011). Sebagian besar (hampir 99 persen), UMKM di Indonesia adalah usaha mikro di sektor informal dan pada umumnya menggunakan bahan baku lokal dengan pasar lokal. Itulah sebabnya tidak terpengaruh secara langsung oleh krisis global. Laporan World Economic Forum (WEF) 2010 menempatkan pasar Indonesia pada ranking ke-15. Hal ini menunjukkan bahwa Indonesia sebagai pasar yang potensial bagi negara lain. Potensi ini yang belum dimanfaatkan oleh UMKM secara maksimal.

Di sisi lain, perkembangan UMKM di Indonesia masih sangat lemah yang terkait dengan willingness to innovate (BPPT and KKBP, 2010), UMKM kurang memiliki kemampuan untuk mengakses sumber daya eksternal, jika dibandingkan dengan perusahaan-perusahaan yang berskala besar (Narula, 2001). Ada beberapa masalah yang umum dihadapi oleh pengusaha kecil mikro dan menengah seperti keterbatasan modal kerja atau modal investasi, kesulitan mendapatkan bahan baku dengan kualitas yang baik dan harga terjangkau, keterbatasan teknologi, sumber daya manusia dengan kualitas yang baik (manajemen dan teknik produksi), informasi pasar, dan kesulitan dalam pemasaran.

Peran dan fungsi Pendidikan Tinggi (Perguruan Tinggi) di masa depan dituntut untuk mampu meningkatkan kualitasnya melalui berbagai program pengembangan, baik yang menyangkut peningkatan efisiensi internal maupun peningkatan efisiensi eksternal bahkan dituntut untuk memiliki program pengembangan unggulan. Program pengembangan ini sejalan dengan jurusan/ program studi yang dikembangkan, tentunya disesuaikan dengan karakteristik yang dimilikinya, sehingga jurusan/program studi menjadi ujung tombak bagi kemajuan perguruan tinggi tersebut menjadi kenyataan.

Dikaitkan dengan dunia ekonomi, dunia bisnis, dunia industri, maka pendidikan memiliki korelasi yang tinggi terhadap pertumbuhan ekonomi suatu negara. Jika negara telah memiliki industri yang maju dan ekonomi yang berkembang maka perlu ditunjang oleh tingkat pendidikan masyarakatnya. Pendidikan yang bermutu mampu meningkatkan produktivitas tenaga kerja melalui peningkatan pengetahuan dan ketrampilan. Peran pendidikan dalam pertumbuhan ekonomi akan terlihat ketika penambahan tenaga kerja yang memiliki produktifitas tinggi sehingga tenaga kerja produktif hasil pendidikan yang baik akan berpengaruh terhadap pertumbuhan ekonomi meskipun tidak secara langsung. Namun dengan adanya pendidikan ini efek penggali terhadap pertumbuhan ekonomi akan menjadi besar serta berkelanjutan. Sebagai sebuah lembaga pendidikan tinggi, diharapkan mampu untuk meningkatkan brand equity di masyarakat dan industri dengan mengembangkan mutu akademis yang akan menghasilkan output yang memiliki keterampilan profesional, berintegritas, beretika, berdedikasi dan berdaya saing. Dengan memperkuat brand equity sebagai alat untuk meningkatkan awareness dan posisi tawar di masyarakat dan dunia industri, yang pada saaatnya akan mampu memiliki daya saing dan dikenal luas baik secara regional. nasional maupun internasional. Hal ini dapat dicapai dengan meningkatkan mutu kelembagaan baik secara akademis maupun profesional dengan memperkuat fungsi kelembagaan.

Strategi pengembangan perguruan tinggi, tentunya tidak lepas dari fungsi untuk memerankan Pelaksanaan Tri Dharma Perguruan Tinggi, yaitu pendidikan, penelitian dan pengabdian masyarakat. Strategi yang dimaksud, harus diarahkan dalam upaya meningkatkan kualitas proses pembelajaran yang dilengkapi dengan sarana dan prasarana pendukung, yang menghasilkan kuantitas dan kualitas lulusan, Penelitian dan pengabdian masyarakat seiring dengan perubahan dan perkembangan yang terjadi di masyarakat dan dunia kerja serta pembinaan kemahasiswaan.

Prof. Dr. Muhammad Abdus Salam, salah seorang ilmuan Muslim dari Pakistan, yang pernah memperoleh hadiah Nobel, 
Rousdy Safari Tamba, Integrasi Peran Pendidikan Tinggi Dalam Penguatan Sektor UMKM...

menyatakan (dalam Muhaimin "Dakwah Islam di tengah Transformasi Sosial" ) : "Tidak diragukan lagi bahwa dari seluruh peradaban di planet ini, sains menempati posisi yang paling lemah dan benar-benar memprihatinkan di dunia Islam. Tidak terlalu berlebihan jika dikatakan bahwa kelemahan ini berbahaya karena kelangsungan hidup suatu masyarakat pada abad ini secara langsung tergantung pada penguasaan atas sains dan teknologi". Pernyataan Prof. Dr. Muhammad Abdus Salam tersebut mengenai faktor-faktor utama penyebab lemahnya semangat scientific inquiry (penyelidikan ilmiah) dari lembaga pendidikan tinggi.

\section{Pendidikan Tinggi dan Sektor UMKM}

Lembaga Pendidikan (Pendidikan Tinggi) memiliki korelasi yang tinggi terhadap pertumbuhan ekonomi, pertumbuhan usaha, pertumbuhan dunia industri suatu negara. Jika negara telah memiliki industri yang maju dan ekonomi yang berkembang maka perlu ditunjang oleh tingkat pendidikan masyarakatnya. Pendidikan yang bermutu mampu meningkatkan produktivitas tenaga kerja melalui peningkatan pengetahuan dan ketrampilan. Peran pendidikan dalam pertumbuhan ekonomi, perkembangan indistri, unit usaha akan terlihat ketika penambahan tenaga kerja yang memiliki produktifitas tinggi sehingga tenaga kerja produktif hasil pendidikan yang baik akan berpengaruh terhadap pertumbuhan ekonomi, dunia industri meskipun tidak secara langsung. Namun dengan adanya pendidikan ini efek penggali terhadap pertumbuhan ekonomi akan menjadi besar serta berkelanjutan.

Peran dan fungsi Pendidikan Tinggi, anatara lain: (1). Peningkatan Kualitas Lulusan; (2). Reformasi institusi; (3). Penyeimbangan antara pertumbuhan dan kualitas manajemen; (4). Peningkatan tanggung jawabsosial dan; (5). Implementasi penjaminan mutu PT (Rokhman, 2015).

Aspek pertama adalah peningkatan kualitas lulusan. Sesuai teori system, lulusan (graduate) adalah bagian yang paling penting dalam sistem pendidikan tinggi, sehingga perlu diciptakan budaya mutu dalam pendidikan tinggi. Teori system ini sangat dipengaruhi oleh input mentah (raw input) dan proses pembelajaran di kampus. University of Philipines (UP) sudah mulai melakukan harmonisasi kompetensi yang berlaku secara internasional. Semua ini dimaksudnya agar lulusannya mampu bersaing secara global pada umumnya dan mampu bersaing di tataran ASEAN. Hal ini lembaga pendidikan tinggi di Indonesia harus mampu berorientasi untuk mengahsilkan lulusan dengan daya saing secara fair di pasar kerja di dalam maupun di dunia kerja internasional.

Aspek kedua adalah pertumbuhan dan kualitas ,manajemen institusi lembaga pendidikan tinggi, disisni lembaga pendidikan tinggi dituntut untuk mewujudkan pertumbuhahnn jumlah mahasiswa dengan jumlah fasilitas dan dosen. Jumlah mahasiswa harus dibarengi dengan kualitas manajemen yang baik dengan mengedepankan penerapan prinsip-prinsip good university governance.

Aspek ketiga adalah kualitas manajemen, disini lembaga pendidikan tinggi diituntuu untuk mampu menerapkan system informasi manajamen (SIM) yang baik, harus menjadi decicion support system artinya SIM mampu menjadikan pimpinan perguruan tinggi dalam mengambil keputusan. Manajemen yang berkualitas adalah tata kelola yang mempunyai komitmen yang tinggi terhadap pengembangan sumber daya manusiabaik tenaga pendidikan maupun tenaga kependidikan. Terkait dengan penjaminan mutu, factor kepemimpinan memiliki peran yang sangat vital dalam penerapan penjaminan mutu tersebut. Model kepemimpinan dengan mengedepankan fasilitasi dan reward akan memacu percepatan.

Aspek keempat adalah tanggung jawab sosial. Tangung jawab sosial lembaga pendidikan tinggi tidak sebatas pada kemampuan melakukan pengandian kepada masyarakat, tetapi meliputi aspek kualitas lulusan yang mampu memenuhi kebutuhan dunia industry maupun kebutuhan masyarakat.

Aspek kelima adalah penjaminan mutu "quality assurance" sangat strategis dalam akselerasi peningkatan mutu 
pergutruan tinggi. Quality Assurance bertugas menetapkan standar mutu baik input, proses maupun out put dan sekaligus melakukan assessment (audit) terhadap pencapaian standar yang telah ditetapkan. Audit mutu internal maupun eksternal akan memberikan informasikepada para pimpinan tentang pencapaian standard sehingga akan memperbaiki aspek-aspek yang masih lemah. Penjaminan mutu juga bertugas untuk melakukan benchmarking untuk standardstandard yang telah ditetapkan oleh lembaga pendidikan tinggi, sehingga dapat dijadikan patokan untuk meningkatkan kualitas mutu.

Jadi dapat disimpulkan bahwa faktorfaktor Pendidikan adalah sesuatu yang ikut menentuksn keberhasilan Pendidikan yang memiliki beberapa bagian yang saling mendukung satu sama lainnya. Faktor-faktor Pendidikan selanjutnya juga disebut dengan komponen-komponen pendidikan.

Menurut Toto Suharto dalam bukunya Filsafat Pendidikan dengan memodifikasi konsepsi Noeng Muhadjir, mengungkapkan secara filosofis komponen-komponen pokok pendidikan kedalam lima komponen, yaitu tujuan pendidikan, pendidik dan peserta didik, kurikulum pendidikan, metode pendidikan, dan konteks pendidikan. Kelima komponen ini adalah merupakan sebuah system, artinya kelima komponen itu merupakan satu kesatuan pendidikan yang masing-masing berdiri sendiri, tetapi berkaitan satu sama lainnya, sehingga terbentuk satu kebulatan yang utuh dalam mencapai tujuan yang diinginkan.

Selanjutnya terkait dengan pemberdayaan UMKM di tengah arus globalisasi dan tingginya persaingan membuat UMKM harus mampu mengadapai tantangan global, seperti meningkatkan inovasi produk dan jasa, pengembangan sumber daya manusia dan teknologi, serta perluasan area pemasaran. Hal ini perlu dilakukan untuk menambah nilai jual UMKM itu sendiri, utamanya agar dapat bersaing dengan produkproduk asing yang kian membanjiri sentra industri dan manufaktur di Indonesia, mengingat UMKM adalah sektor ekonomi yang mampu menyerap tenaga kerja terbesar di Indonesia (Sudaryanto, 2011).

Pemberdayaan UMKM dalam dimensi pembangunan nasional yang berlandaskan system ekonomi kerakyatan, tidak hanya ditujukan untuk mengurangi masalah kesenjangan antar golongan pendapatan dan antar pelaku ataupun penyerapan tenaga kerja. Lebih dari itu pengembangan UMKM yang mampu memperluas basis ekonomi dan dapat memberikan kontribusi yang signifikan dalam mempercepat perubahan structural, yaitu dengan meningkatnya perekonomian daerah dan ketahanan ekonomi nasional. Pengembangan UMKM merupakan prioritas dan menjadi sangat vital (Soedarna, 2001).

Program pemberdayaan, pembinaan dan pengembangan UMKM yang telah dilakukan oleh pemerintah maupun non pemerintah dapat meliputi bidang produksi dan pengolahan, pemasaran, sumber daya manusia, dan teknologi. Di samping itu, pemerintah dan non pemerintah juga telah menyediakan sumber-sumber pembiayaan seperti kredit bank, pinjaman lembaga nonbank, modal ventura, hibah, dan lain-lain. Bentuk-bentuk kemitraan usaha (partnership) juga dikembangkan untuk mendukung akselerasi pengembangan UMKM di Indonesia, dan dengan mengacu pada program pembinaan dan pengembangan UMKM di atas, UMKM-UMKM yang sudah mendapatkan pembinaan, akan terhindar dari masalah-masalah klasik seperti permodalan, pemasaran, manajemen, keterampilan teknis, dan lain-lain (Setiawan, 2004).

Penelitian yang dilakukan Setiawan, (2004) mengkaji dari segi program-program pembinaan yang selama ini telah dilakukan oleh pemerintah maupun non pemerintah, sementara di sisi lain Tambunan, (2009) mengkaji kemampuan UMKM untuk berdaya saing, dimana kemampuan berdaya saing merupakan dampak dari hasil dari programprogram pembinaan yang sudah dilakukan oleh pemerintah maupun nonpemerintah.

Hasil dari program-program pembinaan belum mampu sepenuhnya menghantarkan produk-produk UMKM untuk 
Rousdy Safari Tamba, Integrasi Peran Pendidikan Tinggi Dalam Penguatan Sektor UMKM...

bersaing terhadap produk-produk impor, dan di sisi lain produk-produk UMKM yang ekspor lebih dominan dalam bentuk produk setengah jadi atau produk-produk yang belum difinishing. Diduga bahwa kegagalan program-program pembinaan yang dilakukan oleh pemerintah maupun nonpemerintah disebabkan karena dua factor, yaitu: 1). Pembinaan yang telah dilakukan selama ini belum terstruktur, tidak konsisten dan belum memenuhi aspek keberlanjutan, dan 2). UMKM yang dibina tidak memiliki keseriusan dalam menerima pembinaan. Untuk mengembangkan UMKM maka dua hal pula yang harus dilakukan, yaitu: 1). meningkatkan kualitas pembina, dan kuantitas pembina yang melakukan pembinaan dan pengembangan kepada UKM, dan 2). meningkatkan kesiapan dan kemampuan UMKM untuk dapat lebih mampu berdaya saing, salah satunya dengan membangun mindset UMKM untuk meningkatkan kemampuannya terutama yang terkait dengan kemampuan inovasi produk.

Untuk menghasilkan produk-produk yang mampu berdaya saing sangat tergantung pada kemampuan UMKM untuk melakukan inovasi di berbagai bidang (Tambunan, 2009). Inovasi di berbagai bidang, di antaranya kemampuan inovasi produk, inovasi proses, inovasi servis atau bidang layanan, dan inovasi ini harus dilakukan secara berkesinambungan (O'Regan et al., 2006, Irawan, 2007, Alegre and Chiva, 2008, Tambunan, 2009). Untuk melakukan inovasi secara terus menerus suatu UMKM tidak akan mampu dengan hanya mengandalkan sumber daya yang ada di dalam UMKM itu sendiri, UMKM harus mencoba untuk membuka diri. Chesbrough, (2008) mengungkapkan bahwa jika UMKM membuka diri maka UMKM memiliki peluang untuk memajukan usahanya, dan pihak-pihak eksternal akan datang untuk menawarkan berbagai solusi dari permasalahan-permasalahan yang dihadapi UMKM tersebut, bahkan UMKM dalam perkembangannya memerlukan suatu pendamping, atau perantara (intermediary) yang berperan penting untuk melakukan pembinaan dan pengembangan terhadap UMKM-UMKM tersebut.

\section{Peran Perguruan Tinggi dalam Penguatan Sektor UMKM}

Peran Perguruan Tinggi sangatlah penting dalam perkembangan masyarakat bahkan sampai saat ini masyarakat masih mempercayakan kepada perguruan tinggi sebagai lembaga pendidikan tinggi yang masih memiliki kekuatan moral untuk menjadi panutan masyarakat dalam transformasi menuju masyarakat global, sekaligus perguruan tinggi memiliki peran yang sangat besar dalam memberdayakan kewirausahaan, memperdayakan UMKM, sehingga UKM dapat berfungsi sebagai motor penggerak ekonomi kerakyatan. Untuk itu perguruan tinggi diharapkan dapat melakukan temuan-temuan baru di bidang ilmu pengetahuan dan inovasi yang dapat meningkatkan kemajuan masyarakat. Terkait dengan link and match antara perguruan tinggi dan UMKM, hendaknya terdapat kerjasama yang saling mengisi. Dimana perguruan tinggi berperan sebagai sumber pembelajaran dan UMKM sebagai partner dalam mengembangkan sains dan teknologi. Peran perguruan tinggi bukan pada pemberian modal tetapi lebih pada membina kemampuan industri kecil sehingga mendorong kemampuan industri kecil dalam mengakses modal. Dengan kata lain perguruan tinggi membina kemampuan industri kecil dalam menghitung modal yang diperlukan, serta menyusun suatu proposal pendanaan ke lembaga-lembaga pemberi modal. Kolaborasi antara perguruan tinggi dengan UMKM diharapkan dapat memberikan solusi pada masalah yang dihadapi UKM seperti pemasaran, keuangan, pengembangan produk dan teknologi, serta pengembangan manajemen. Berdasarkan kondisi tersebut sudah selayaknya jika perguruan tinggi berperan aktif dalam pengembangan kewirausahaan karena akan memberikan dampak yang efektif bagi wirausaha kecil

Sijabat (2011) dalam artikelnya
tentang UMKM menyatakan bahwa pemberdayaan entrepreneurship terutama yang terlihat pada UMKM merupakan solusi terbaik untuk mengoptimalkan potensi sumber daya nasional, sesuai amanat pasal (4) dan pasal (5) UU Nomor 20 Tahun 2008. 
Sedang Kumorotomo, W. (2008) mengatakan perlu upaya menggiatkan kewirausahaan berupa penguatan kelembagaan pada UMKM. Upaya ini dapat dilaksanakan dengan strategi (1) perluasan akses pada sumber permodalan, terrutama perbankan; (2) memperbaiki lingkungan usaha dan prosedur perizinan dan; (3) memperluas dan meningkatkan kualitas institusi pendukung non-finansial, dari sini sangat jelas lembaga nonkeuangan dan perbankan yaitu lembaga pendidikan tinggi dituntut untuk terlibat secara langsung dalam penguatan sektor UMKM. Begitu strategisnya peran perguruan tinggi, sebagaimana diungkapkan Rasyid (2007) dalam penelitiannya yang merekomendasikan perlunya dilakukan kegiatan pemberdayaan.

Peningkatan Linkage Pendidikan

Tinggi Terhadap UMKM, dapat diwujudkan dalam Rencana Strategis (RENSTRA) Perguruan Tinggi, antara lain dengan:

1. Membentuk Jaringan Kerjasama dengan UMKM.

2. Melaksanakan kegiatan Road Show Kerjasama dengan UMKM dan

3. Mengembangkan program magang komprehensif berdasarkan pendekatan proyek.

Secara konkret wujud kerja sama strategis di bidang tridharma perguruan tinggi maupun profesional yang terintegrasi dengan UMKM yang dapat dilakukan dalam pengembangan kelembagaan, antara lain:

1. Pengembangan kerjasama di bidang pengabdian kepada masyarakat melalui pengembangan jejaring dengan UMKM guna memberikan nilai tambah dan kemanfaatan lembaga di masyarakat

2. Pengembangan kapasitas lembaga dengan membangun dan mengembangkan jejaring dengan UMKM, industri, asosiasi profesi untuk mengembangkan kapasitas lembaga pada pendekatan yang lebih bisnis-sentris.

3. Pengembangan brand equity dan eksposur kelembagaan dengan keterlibatan lembaga dalam kegiatan-kegiatan profesional melalui penguatan fungsi strategis laboratorium dan lembaga kajian

\section{Simpulan}

Kualitas SDM bagi bangsa Indonesia merupakan suatu aset negara yang sangat penting dan memiliki peranan yang sangat besar bagi kelangsungan hidup bangsa Indonesia, artinya kelangsungan hidup bangsa Indonesia hari ini dan kedepan, tidak bisa hanya mengandalkan dan tergantung kepada kekayaan dari Sumberdaya alam (SDA) yang luar biasa dan tenaga kerja yang murah.

Lembaga pendidikan tinggi, dituntutan untuk berperan di masa depan diarahkan untuk mampu meningkatkan daya saing bangsa yang dilandasi oleh adanya otonomi penyelenggaraan pendidikan dan organisasi kelembagaan yang sehat, dengan solusi berbasis pengetahuan "knowledge-based solutin" dengan kata lain bahwa daya saing tersebut semakin tidak bergantung lagi pada kekayaan alam dan tenaga kerja yang murah.

Banyak negara berkembang yang beralih status menjadi negara maju karena telah jauh masa melakukan investasi dalam sektor pendidikan. Kemajuan dan kemampuan dalam mewujudkan sebagai bangsa yang memiliki daya saing tersebut, tidak lepas dari pembangunan dan pertumbuhan ekonomi bangsa, khususnya UMKM, dimana UMKM ini memiliki peran dan fungsi dalam pembangunan dan pertumbuhan ekonomi Indonesia memainkan peranan yang sangat vital bahkan tidak saja di negara-negara sedang berkembang, tetapi juga di negaranegara maju. Di satu sisi perkembangan UMKM di Indonesia masih sangat lemah yang terkait dengan willingness to innovate (BPPT and KKBP, 2010), UMKM kurang memiliki kemampuan untuk mengakses sumber daya eksternal, jika dibandingkan dengan perusahaan-perusahaan yang berskala besar.

Peranan UMKM yang sangat strategis tersebut mau tidak mau Pemerintah harus terus menerus mendorong dan memeperdayakan UMKM untuk menopang kokohnya fundamental perekonomian Indonesia.

Pendidikan memiliki korelasi yang tinggi terhadap pertumbuhan ekonomi suatu 
Rousdy Safari Tamba, Integrasi Peran Pendidikan Tinggi Dalam Penguatan Sektor UMKM...

negara. Peningkatan Linkage Pendidikan Tinggi Terhadap UMKM, dengan Tri Dharma perguruan tinggi, dapat diwujudkan dalam Rencana Strategis (RENSTRA) Perguruan Tinggi, dalam bentuk (1) mbentuk Jaringan Kerjasama dengan UMKM;

Melaksanakan kegiatan Road Show Kerja sama dengan UMKM; (3) Mengembangkan program magang komprehensif berdasarkan pendekatan proyek; dan (4) Pengembangan brand equity dan eksposur kelembagaan dengan keterlibatan lembaga dalam kegiatankegiatan profesional melalui penguatan fungsi strategis laboratorium dan lembaga kajian.

Daftar Kepustakaan

Lembaga Intermediary (LI) (BPPT and

KKBP, 2010)

Laporan World Economic Forum (WEF)

2010

Rokhman, Fathur. 2015. Strategi Perguruan Tinggi dalam Menghadapi Masyarakat Ekonomi ASEAN, Pidato Ilmiah dalam rangka Dies Natalis ke 1 Universitas Tidar, 1 April 2015

Kumorotomo W. 2008. Perubahan Paradigma Pemerintah dalam Pemberdayaan Koperasi dan UMKM

Muhaimin, "Dakweah Islam di Tengah Transformasi Sosial": Penerbit Karya Aditama Surabaya; tt

Rasyid, R. 2007. "Keterkaitan Perguruan Tinggi Dalam Pemberdayaa Usaha Kecil Mikro (UKM) di Sumatera Barat". Jurnal Eksekutif. (Vol. 4 No. 3) : 217230

Sijabat. S. 2011. "Dampak Penerapan Undang-Undang No. 20 Tahun 2008 Tentang UMKM Terhadap Pengembangan Kewirausahaan Bagi UMKM". Jurnal Infokop. (vol. 19): 86-103

Sudaryanto. 2011. "The Need for ICTEducation for Manager or Agribusinessman to Increasing
Farm Income: Study of Factor Influences on Computer Adoption in East Java Farm Agribusiness". International Journal of Education and Development, JEDICT, Vol 7 No $1 \mathrm{hlm} .56-67$

Sudarno. 2012. "Kontribusi usaha mikro, kecil, dan menengah (UMKM) dalam penyerapan tenaga kerja”. Jurnal Penelitian dan pengembangan Humanoria. 9(1): 68-76.

Tambunan, Tulus 2000, Perkembangan Industri Skala Kecil di Indonesia, Jakarta: PT Mutiara Sumber Widya.

Tambunan, Tulus 2003, Perkembangan UKM dalam Era AFTA: Peluang, Tantangan, Permasalahan dan Alternatif Solusinya. Paper Diskusi pada Yayasan Indonesia Forum

Tambunan, T.T.H., 2008, "Masalah Pengembangan UKM di Indonesia: Sebuah Upaya Mencari Jalan Alternatif', Makalah, diakses dari http://www.kadin-indonesia.or.id pada 1 Mei 2010

Tambunan, Tulus. 2001, Perdagangan Internasional dan Neraca Pembayaran, Teori dan Temuan Empiris, Jakarta: LP3ES

2010, Center for Industry, SME and Business Competition Studies. Jakarta: Trisakti University

,World Economic Forum (WEF), 2011 dalam http:/ /www.bappenas.go.id/blog/ wpcontent/ uploads/2012/10/2_PERINGKA T-DAYA-SAING-INDONESIA2011-hary- Dralat.pdf

http://lokapau.blogspot.co.id/2014/09/fakto r-faktor-pendidikan-a.html 